\title{
Ruokohelven briketöinti
}

Jussi Laurila ja Risto Lauhanen. Seinäjoen ammattikorkeakoulu, Maa- ja metsätalouden yksikkö, Tuomarniemi, Tuomarniementie 55, 63700 Ähtäri.jussi.laurila@seamk.fi ja risto.lauhanen@seamk.fi

Tutkimuksen tavoitteena oli selvittää ruokohelven (Phalaris arundinacea) korjuun, murskauksen ja briketöinnin työvaiheita sekä kustannuksia. Lisäksi tarkasteltiin ruokohelpibrikettien ominaisuuksia ja soveltuvuutta lämmöntuotantoon. Ruokohelven logistisia virtoja viljelyksiltä loppukäyttöön selvitettiin Etelä-Pohjanmaan tavoite 2 -alueella yhteistyössä Kuortaneen energiaosuuskunnan kanssa. Projektin rahoittivat EU/EAKR, Etelä-Pohjanmaan TE-keskus, Seinäjoen ammattikorkeakoulu sekä mukana olleet käytännön tahot.

Tuhannen kilogramman ruokohelpierän murskaamiseen kului aikaa 3 h $18 \mathrm{~min}$. Murskan keskimääräinen tuottavuus oli $303 \mathrm{~kg} / \mathrm{h}$. Briketöintikoneen tuottavuus oli $314 \mathrm{~kg} / \mathrm{h}$. Tuhannen kilogramman brikettierän valmistamiseen kului aikaa $3 \mathrm{~h} 11 \mathrm{~min}$.

Brikettien irtotiheys oli $530 \mathrm{~kg} / \mathrm{m}^{3}$ ja kiintotiheys $990 \mathrm{~kg} / \mathrm{m}^{3}$. Ruokohelpibrikettien kosteudeksi mitattiin $10,9 \%$ ja tuhkapitoisuudeksi $2,9 \%$. Brikettien tehollinen lämpöarvo oli saapumistilassa 4,4 $\mathrm{MWh} / \mathrm{t}$. Kuiva-aineen teholliseksi lämpöarvoksi määritettiin 5,0 MWh/t.

EU-tuilla oli merkittävä vaikutus ruokohelven viljelyn kannattavuuteen. Kasvinviljelytilalla C1alueella (Kuortane) EU-tuet olivat yhteensä $563 € /$ ha. Mikäli keskimääräiseksi sadoksi oletettiin 5000 $\mathrm{kg} / \mathrm{ha}$, niin ruokohelpitonnia kohti laskettuna kasvinviljelytilalla $\mathrm{C} 1$-alueella tuen suuruus oli noin 113 $€ / \mathrm{t} \mathrm{ja} 7000 \mathrm{~kg} / \mathrm{ha}$ satotasolla tuen suuruus oli noin $80 € / \mathrm{t}$.

Automatisoimattomalla murskauslinjalla ruokohelpipaalien murskauksen kustannukset olivat 63 $€ / t$ ja automatisoidulla linjalla $22 € /$ t. Briketöinnin kustannukset olivat $15 € /$ t. Laskemalla yhteen ruokohelven viljelystä ja korjuusta aiheutuneet kustannukset, kaukokuljetuskustannukset, murskauskustannukset ja briketöintikustannukset EU-tuet huomioiden, saatiin valmiiden brikettien tuotantokustannuksiksi $58 € / \mathrm{t}$ (automatisoimaton murskauslinja satotasolla $5000 \mathrm{~kg} / \mathrm{ha}$ ). Automatisoidulla murskauslinjalla ja $5000 \mathrm{~kg} / \mathrm{ha}$ satotasolla kustannukset olivat $17 € /$ t. Satotasolla $7000 \mathrm{~kg} / \mathrm{ha}$ ja automatisoimattomalla murskauslinjalla kustannukset olivat $77 € / t$, kun automatisoidulla murskauslinjalla kustannukset olivat $36 € /$ t.

Pilottihankkeessa kyettiin valmistamaan hyvälaatuista ruokohelpibrikettiä, jonka kiintotiheys oli yli kuusinkertainen ruokohelpipyöröpaalien kiintotiheyteen verrattuna. Tiheyden nousu pienentää huomattavasti varastotilan tarvetta sekä alentaa kuljetuskustannuksia. Ruokohelpi soveltuu briketöitäväksi myös seospolttoaineena puunjalostusteollisuuden sivutuotepurujen kanssa. Briketit ovat helppoja käsitellä ja niiden energiatiheys on suuri. Briketit soveltuvat poltettavaksi suurten lämpölaitosten lisäksi myös pienissä lämpölaitoksissa, maatiloilla ja kotitalouksissa. Briketöinti luo ruokohelven käytölle uusia käyttökohteita ja avaa mahdollisuuksia kilpailla laajemmilla biopolttoainemarkkinoilla.

Asiasanat: bioenergia, briketti, briketöinti, Etelä-Pohjanmaan tavoite 2 -alue, Kuortane, murskaus, Phalaris arundinacea, ruokohelpi 


\section{Johdanto}

Ruokohelven biologinen kuiva-ainesato on keskimäärin 7000 kg/ha/v. Ruokohelven lämpöarvo kuivaaineesta on noin 4,9 MWh/t. Teoriassa hehtaarin helpisato sisältää energiaa noin $34 \mathrm{MWh}$. Määrä vastaa suunnilleen 1,5 omakotitalon $\left(140 \mathrm{~m}^{2}\right)$ vuotuista lämmöntarvetta (sis. käyttöveden lämmityksen 5 henkilölle). Vastaavan energiamäärän tuottamiseen tarvittaisiin noin 3500 litraa kevyttä polttoöljyä. Fossiilisten polttoaineiden korvaaminen ruokohelvellä vähentää hiilidioksidipäästöjä, työllistää ihmisiä maaseudulla ja lisää maamme energiaomavaraisuusastetta.

Ruokohelpipyöröpaalien tiheys on melko alhainen ja paalin sylinterimäinen muoto on epäedullinen tilankäytön kannalta. Edellä mainituista tekijöistä johtuen paalien varastotilan tarve on suuri ja taloudellinen kaukokuljetusmatka jää melko lyhyeksi. Logistiikan kannalta ruokohelpi olisi saatava helpommin käsiteltävään muotoon. Ongelmaan löytyy yksi ratkaisu briketöinnistä, jolla ruokohelpipolttoaineen tiheys voidaan nostaa moninkertaiseksi paaleihin verrattuna. Briketit ovat helppoja käsitellä, edullisia kuljettaa ja niitä voidaan käyttää monenlaisissa käyttökohteissa.

Tämän tutkimuksen tavoitteena oli selvittää ruokohelven (Phalaris arundinacea) korjuun, murskauksen ja briketöinnin työvaiheita sekä kustannuksia Etelä-Pohjanmaan tavoite 2 -alueella Kuortaneella. Lisäksi tarkasteltiin ruokohelpibrikettien ominaisuuksia ja soveltuvuutta lämmöntuotantoon. Ruokohelven korjuuta seurattiin Veli-Matti Ruismäen ruokohelpiviljelmillä Kuortaneen Ruismäessä. Briketöintiä edeltävää murskausta havainnoitiin Vest-Wood Suomi Oy:n tuotantolaitoksessa Kuortaneen Leppälänkylässä. Briketöinti tapahtui Kuortaneen energiaosuuskunnan briketöintilaitoksessa Leppälänkylässä. Briketin polttokokeet suoritettiin Kuortaneen energiaosuuskunnan lämpölaitoksessa Kuortaneen vanhainkodilla.

\section{Aineisto ja menetelmät}

Tutkimusaineisto kerättiin Kuortaneen Ruismäessä Veli-Matti Ruismäen ruokohelpiviljelmillä. Viljelmät oli perustettu vuonna 2004 ja ensimmäinen sato niiltä korjattiin keväällä 2006. Ruokohelpiviljelmät sijaitsivat viidellä eri lohkolla lähellä toisiaan. Kaikkien lohkojen maalajina oli multamaa. Lohkojen pinta-alat olivat $1,14-1,95$ ha ja yhteispinta-ala 7,20 ha. Korjuu aloitettiin 29.4.2006, tällöin lumien sulamisesta oli kulunut vain muutama vuorokausi. Niiton sekä paalauksen osalta korjuu saatiin päätökseen 2.5.2006. Lähikuljetus suoritettiin lohkon 1 osalta välittömästi paalauksen jälkeen, mutta muilta lohkoilta vasta myöhemmin.

Ruokohelpi niitettiin 29.4.2006 maataloustraktoriin kytkettävällä John Deeren valmistamalla 1365-niittomurskaimella. Niittomurskain pyrittiin säätämään siten, että ruokohelpi saataisiin korjattua talteen mahdollisimman vähin korjuutappioin. Sato leikattiin läheltä maanpinnan tasoa ja niittomurskaimen ulostuloaukot säädettiin mahdollisimman väljiksi. Niittämiseen kulunut aika mitattiin yhteisajanmenekkinä, jossa mukana olivat kaikki lohkot 1-5. Niitosta aiheutuneita kustannuksia laskettaessa käytettiin urakoitsijan ilmoittamia todellisia taksoja.

Lohko 1 paalattiin Claas Rollant 62 -merkkisellä pyöröpaalaimella, mutta ko. paalain ei soveltunut ruokohelven paalaamiseen lohkolla vallitsevissa olosuhteissa. Paalaimen noukin oli liian kapea ja sidonta oli mahdollista suorittaa vain narulla. Edellä mainituista syistä johtuen paalainta päätettiin vaihtaa ja ottaa käyttöön kiinteäkammioinen Claas Rollant 250 -pyöröpaalain, jonka noukin oli leveämpi ja sidonta voitiin suorittaa verkkoa käyttäen. Rollant 250 -koneella paalattiin lohkot 2-5.

Paaleja tehtiin yhteensä $147 \mathrm{kpl}$, joista neljä rikkoutui paalatessa. Paalaukseen kulunutta ajanmenekkiä tarkkailtiin lohkoittain sekä yhden paalin paalaamiseen kuluvan ajan osalta. Yksittäisen paalin paalaamiseen kulunutta aikaa tarkkailtiin 54 paalin osalta. Lohkolla 1 aikaa kului kohtuuttoman paljon koneen säätämiseen. Tämän takia tuloksia laskettaessa lohkolla 1 on käytetty lohkojen 2-5 mittauksista laskettua keskimääräistä ajanmenekkiä pinta-alaan suhteuttaen.

Lohkoilta 2-5 punnittiin satunnaisesti 10 paalia/lohko ja lohkolta 1 punnittiin 6 paalia. Massan punnituksessa käytettiin Dynamic Platforms -merkkistä ajoneuvovaakaa. Vaaka oli asetettu traktorin peräkärryyn, josta laidat oli poistettu. Punnittujen paalien massoista laskettiin keskimääräiset lohkokohtaiset paalien massat, joita käytettiin lohkokohtaisten ruokohelpisatojen laskennassa.

Lähikuljetus lohkoilta välivarastoon tapahtui maataloustraktorilla, johon oli kytketty pyöröpaalien kuljetukseen soveltuva perävaunu. Perävaunun kuormaus ja purku suoritettiin etukuormaajalla varustetulla maataloustraktorilla. Lähikuljetukseen kulunutta aikaa seurattiin lohkoittain. 
Ruokohelven briketöintiä havainnoitiin 20.5.2006 Kuortaneen energiaosuuskunnan tuotantolaitoksessa Kuortaneen Leppälänkylässä. Ruokohelpipaalit murskattiin ensin Vest-Wood Suomi Oy:n tuotantolaitoksessa niin ikään Leppälänkylässä. Murskauksen ja briketöinnin tuottavuutta selvitettiin mittaamalla aikaa, joka kului tietyn ruokohelpierän käsittelyyn. Aineistoa kerättiin yhteensä kuudesta ruokohelpipyöröpaalista ja niiden murskauksesta sekä briketöinnistä. Briketöintihallin läheisyydessä oli käytössä Dynamic Platforms -merkkinen ajoneuvovaaka, jolla murskattavien paalien massa punnittiin ennen murskausta. Yhteensä ruokohelpeä murskattiin ja briketöitiin $1390 \mathrm{~kg}$. Paalien kosteuspitoisuus mitattiin Wile 25 -digitaalisella kosteusmittarilla.

Ruokohelpipyöröpaalit murskattiin ennen briketöintiä Weima WL 15 -merkkisellä roottorimurskaimella, joka oli varustettu $55 \mathrm{~kW}$ :n sähkömoottorilla. Laitteen roottorin leveys oli $1500 \mathrm{~mm}$, halkaisija $386 \mathrm{~mm}$ ja siinä oli 100 terää. Laitteen murskauskapasiteettia selvitettiin mittaamalla murskattavien ruokohelpipaalien massa ja paalien murskaamiseen kulunut aika. Murskauksen kustannuksia laskettaessa käytettiin jälleenmyyjän ilmoittamaa $(30 \mathrm{~kW} / \mathrm{h})$ arviota sähkönkulutuksesta ruokohelpipaaleja murskattaessa.

Briketöinti aloitettiin noin 20 minuuttia myöhemmin kuin paalien murskaus. Molemmat koneet (murskain ja briketöintikone) kävivät käynnistämisen jälkeen keskeytyksettä kokeen loppuun saakka. Briketöinti tehtiin Adelmann BP550 -merkkisellä briketöintikoneella (kuva 1), jonka puristinosan nimellishalkaisija oli $55 \mathrm{~mm}$. Briketöintikoneen tuotosta selvitettiin 100 litran näyte-erällä, jonka massa ja valmistamiseen kulunut aika mitattiin. Lisäksi määritettiin brikettien kiintotiheys. Kiintotiheyttä määritettäessä briketin tilavuus laskettiin sylinterin kaavaa käyttäen ja massa punnittiin laboratoriovaa'alla.

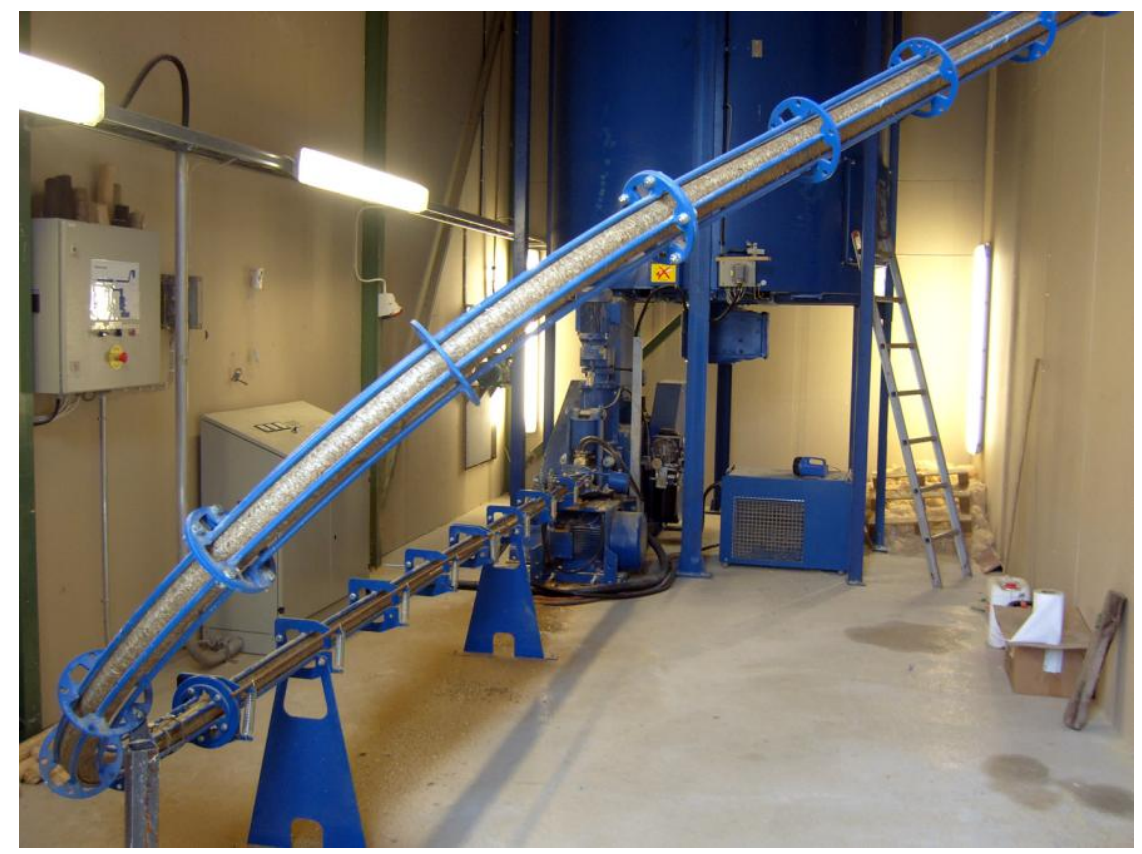

Kuva 1. Briketöintikone asennettuna sisätiloihin. Etualalla kuljetin, jota pitkin briketit siirretään viereiseen varastorakennukseen oikealle. (Kuva: Jussi Laurila)

Ruokohelpibrikettien ominaisuuksia testattiin sekä laboratoriossa että lämpölaitoksessa. Laboratorioanalyysit tehtiin Vaskiluodon Voima Oy:n Seinäjoen voimalaitoksen (SEVO) laboratoriossa. Laboratoriossa briketistä määritettiin kosteus, tuhkapitoisuus, tehollinen lämpöarvo kuiva-aineesta ja tehollinen lämpöarvo käyttökosteudessa.

Ruokohelpibrikettien polttoa seurattiin lämpölaitoksessa Kuortaneella, jossa oli Tulostekniikan valmistama $700 \mathrm{~kW}$ :n lämpökattila. Kattilassa oli viistoporrasarina. Briketistä vapautuva lämpöenergia määritettiin polttamalla $1600 \mathrm{~kg}$ ruokohelpibrikettiä, josta vapautunut lämpöenergia mitattiin lämpölaitoksen energiamittarilla. Energiamittarin mittaustuloksessa ei ole mukana hukkalämpöä, vaan tulos kuvaa lämpölaitokselta lähtevää todellista energiamäärää. Laitoksen hyötysuhteeksi on aikaisempien päästömittausten yhteydessä mitattu $85 \%$. 


\section{Tulokset ja tulosten tarkastelu Korjuu ja varastointi}

Niiton tuottavuus oli $1,6 \mathrm{ha} / \mathrm{h}$ ja kustannukset $30 € /$ ha. Niiton tuntitaksaksi saatiin noin $47 € / \mathrm{h}$. Paaleja paalattiin yhteensä $147 \mathrm{kpl}$. Yhteensä 7,2 ha ruokohelpialan paalaamiseen kului aikaa $6 \mathrm{~h} 57 \mathrm{~min}$. Paalauksen tuottavuudeksi saatiin noin $1 \mathrm{ha} / \mathrm{h}$. Yhden pyöröpaalin paalauskustannukset olivat $5,5 € \mathrm{ja}$ hehtaarikohtaiset kustannukset olivat keskimäärin $109 €$.

Punnittujen paalien keskimääräinen massa oli $233 \mathrm{~kg}$. Paalien massojen vaihteluväli oli 114 $298 \mathrm{~kg}$ keskihajonnan ollessa $36 \mathrm{~kg}$. Paalien halkaisija oli $125 \mathrm{~cm}$, leveys $120 \mathrm{~cm}$ ja tilavuus $1,47 \mathrm{~m}^{3}$. Keskimääräiseksi paalin tiheydeksi saatiin $158 \mathrm{~kg} / \mathrm{m}^{3}$. Esimerkiksi puuhun verrattuna tiheys on alhainen. Alhaisesta tiheydestä johtuen ruokohelpipaalien taloudellinen kaukokuljetusmatka jää melko lyhyeksi.

Ruokohelven hehtaarisato oli lohkoittain 3558 - 5160 kg/ha. Keskimääräinen hehtaarisato oli $4638 \mathrm{~kg} / \mathrm{ha}$ ja lohkoittainen hehtaarisatojen keskihajonta oli $638 \mathrm{~kg}$. Lohkolla 1 käytettiin erilaista paalainta kuin muilla lohkoilla. Paalain jouduttiin vaihtamaan, koska se ei soveltunut ruokohelven kevätkorjuuseen vallitsevissa olosuhteissa. Lohkon 1 alhainen hehtaarisato $(3558 \mathrm{~kg} / \mathrm{ha})$ johtuikin todennäköisesti ensimmäisen paalaimen aiheuttamista suurista korjuutappioista.

Korjuutappioita ei tässä tutkimuksessa mitattu, mutta silmämääräisesti arvioiden niitä voitiin selkeästi havaita mm. paalauksen yhteydessä. Todennäköisesti käyttämällä joko muuttuvakammioista pyöröpaalainta tai kanttipaalainta voitaisiin korjuutappiota jonkin verran vähentää. Kirjallisuuden perusteella suurimmat korjuutappiot aiheutuvat kuitenkin niitossa.

Paalien lähikuljetus pellolta välivarastoon suoritettiin etukuormaajalla varustetulla maataloustraktorilla, johon oli kytketty paalien kuljetukseen soveltuva peräkärry. Yhdistelmällä voitiin kuljettaa helposti noin 10 pyöröpaalia kerralla. Tällöin kuorma ei ollut liian raskas ja se oli helppo sekä kuormata että purkaa eikä se myöskään aiheuttanut raiteita peltoon eikä teihin. Kaukokuljetuksessa perävaunuun voitiin lastata 18-24 paalia. Kuormauksen ja purkamisen ajaksi peräkärry täytyi irrottaa traktorin peräkoukusta. Käyttämällä kahta traktoria voitaisiin kuormausta ja purkua hieman nopeuttaa, mutta toisaalta kahdesta työkoneesta aiheutuisi suuremmat kustannukset. Paalit varastoitiin joko peltolohkoille tai peltojen läheisyydessä sijaitsevaan tilavaan puurakenteiseen latoon. Lähikuljetuksessa kuorman (10 paalia) lastaukseen, siirtoon ja purkuun kului aikaa 20-30 min. Lähikuljetuksesta aiheutui kustannuksia noin $25 € / \mathrm{h}$.

\section{Murskaus, briketöinti ja poltto}

Paaleja murskattiin yhteensä $6 \mathrm{kpl}$ ja niiden murskaamiseen kului aikaa 4 h 35 min. Paalien keskimääräinen kosteus oli 9,3\%, yhteismassa $1390 \mathrm{~kg}$ ja keskimääräinen massa oli $232 \mathrm{~kg}$. Yhden paalin murskaamiseen kului aikaa keskimäärin $46 \mathrm{~min}$. Briketöintikone käynnistettiin noin 20 minuuttia myöhemmin kuin paalien murskaus alkoi. Käynnistämisen jälkeen sekä murskain että briketöintikone kävivät keskeytyksettä kokeen loppuun saakka. Koneiden keskinäiset tuotokset olivat suunnilleen samansuuruisia. Sadan litran näyte-erän perusteella briketöintikoneen tuottavuus oli $314 \mathrm{~kg} / \mathrm{h}$. Tuhannen kilogramman brikettierän valmistamiseen kuluu aikaa $3 \mathrm{~h} 11 \mathrm{~min}$. Briketin irtotiheydeksi saatiin $530 \mathrm{~kg} / \mathrm{m}^{3}$ ja kiintotiheydeksi $990 \mathrm{~kg} / \mathrm{m}^{3}$. Kahdeksan tunnin työpäivässä brikettejä ehditään valmistaa noin $2500 \mathrm{~kg}$.

Vaskiluodon Voima Oy:n Seinäjoen lämpölaitoksen (SEVO) laboratoriossa ruokohelpibrikettien kosteudeksi mitattiin 10,9\% ja tuhkapitoisuudeksi $2,9 \%$. Brikettien tehollinen lämpöarvo käyttökosteudessa oli 4,4 MWh/t. Kuiva-aineen teholliseksi lämpöarvoksi määritettiin 5,0 $\quad \mathrm{MWh} / \mathrm{t}$.

Ruokohelpibrikettien lämpölaitospolttokoe tehtiin viikolla 25 , jolloin sää oli poutainen ja lämmin. Lämpölaitoksella brikettien lämpö-arvoksi saatiin 3,4 MWh/t, joka ei sisällä hukkalämpöä. Brikettien lämpö-arvo, jossa mukana on myös hukkalämpö, voidaan laskea, kun lämpölaitoksen hyötysuhde tunnetaan. Aikaisemmin suoritetussa päästömittauksessa lämpölaitoksen hyötysuhteeksi on saatu $85 \%$. Tällä lukuarvolla laskien saadaan ruokohelpibrikettien lämpöarvoksi 4,0 MWh/t. Todellisuudessa lämpölaitoksen hyötysuhde vallitsevissa polttokoeolosuhteissa saattoi olla alle $85 \%$, johtuen mm. vähäisestä lämmönkulutuksesta. Alhaisesta kulutuksesta johtuen lämpölaitos kävi tyhjäkäyntiä ja välillä jopa pysähtyi. Laitoksen energiamittarin mukaan lämpölaitokselta lähtevän lämpöenergian määrä oli vain 30-100 kW. Poltossa havaittiin, että palopäähän kertyi tuhkaa. Tuhka aiheutti hieman 
ongelmia myös arinalla. Tuloksia tarkasteltaessa on huomioitava kokeen aikana vallinnut pieni lämmönkulutus, joka saattaa vaikuttaa tulosten luotettavuuteen.

\section{Kustannukset ja kannattavuus}

EU-tuilla oli merkittävä vaikutus ruokohelven viljelyn kannattavuuteen. Kasvinviljelytilalla C1alueella (Kuortane) tuet olivat yhteensä $563 € /$ ha. Mikäli keskimääräiseksi sadoksi oletetaan 5000 $\mathrm{kg} / \mathrm{ha}$, niin ruokohelpitonnia kohti laskettuna kasvinviljelytilalla $\mathrm{C} 1$-alueella tuen suuruus oli noin 113 $€ / \mathrm{t} \mathrm{ja} 7000 \mathrm{~kg} / \mathrm{ha}$ satotasolla tuen suuruus oli noin $80 € / \mathrm{t}$.

Ruokohelven tuotantokustannuksia tarkasteltaessa viljelmän perustamisen, viljelyn lopettamisen ja hoidon osalta käytettiin osittain MTT:n tutkimuksen (2005) lukuarvoja. Korjuukustannuksina käytettiin yrittäjän ilmoittamia taksoja ja maan arvona käytettiin keskimääräistä peltohehtaarihintaa Kuortaneella.

Vähentämällä C1-alueen kasvinviljelytilan EU-tuista (563 €/ha) ruokohelven tuotantokustannukset (466 €/ha) saadaan tulokseksi $97 € /$ ha ja noin $19 € /$ t, kun satotasoksi oletetaan 5 t/ha. Mikäli satotasoksi oletetaan $7000 \mathrm{~kg} / \mathrm{ha}$, niin saadaan tulokseksi noin $12 € /$ ha ja noin $2 € /$ t. Suurimmat kustannukset ruokohelven tuotannossa aiheutuu korjuusta (sis. lähi- sekä kaukokuljetuksen) ja pääomakustannuksista. Pääoman vaihtoehtoisen tuoton tuottovaatimukset vaikuttavat ratkaisevasti tuotantokustannuslaskelman tulokseen.

Murskauksen tuotantokustannuslaskelmissa käytettiin kahta eri henkilötyön määrää: vaihtoehto 1 "automatisoimaton murskauslinja" $20 \mathrm{~h} / \mathrm{vrk}$ ja vaihtoehto 2 "automatisoitu murskauslinja" $2 \mathrm{~h} / \mathrm{vrk}$. Henkilötyön määrään vaikuttaa murskauslinjan automatisointiaste. Kokeen suorittamishetkellä murskauslinja ei ollut varustettu automaattisella paalinsyöttölinjalla, joten murska sitoi käytännössä yhden työntekijän koko murskauksen ajan. Automaattisella paalinsyöttölinjalla murskauksessa tarvittavan henkilötyön määrä voitaisiin alentaa kahteen tuntiin vuorokaudessa. Briketöintikustannuksia laskettaessa henkilötyönmääränä käytettiin $1 \mathrm{~h} / \mathrm{vrk}$.

Murskauksesta ja briketöinnistä aiheutui kustannuksia yhteensä $78 € / \mathrm{t}$, kun murskauksen palkkakustannustunteina käytettiin 20 h/vrk. Kustannukset olivat huomattavasti alemmat, yhteensä $37 € /$, mikäli murskauksen vaatimina palkkakustannustunteina käytettiin $2 \mathrm{~h} / \mathrm{vrk}$. Murskauksen ja briketöinnin kustannuslaskelmissa on oletettu, että koneita käytetään kolmessa vuorossa. Tällöin koneiden tuotantokapasiteetti on $1500000 \mathrm{~kg} / \mathrm{v}$. Tällaisen ruokohelpimäärän tuottamiseen tarvittaisiin peltoa 300 ha, kun satotasoksi oletetaan $5000 \mathrm{~kg} / \mathrm{ha}$.

Taulukossa 1 esitetään yhteenveto ruokohelven viljelystä, korjuusta, murskauksesta ja briketöinnistä aiheutuvista kustannuksista sekä EU-tuista. Laskelmat on tehty kahdella eri satotasolla: 5000 $\mathrm{kg} / \mathrm{ha}$ ja $7000 \mathrm{~kg} / \mathrm{ha}$. Laskemalla ruokohelven viljelyn ja korjuun kustannukset, murskauksen kustannukset ja briketöinnin kustannukset yhteen EU-tuet huomioiden saadaan tulokseksi $58 € / t$, kun murskauksen vaatimana palkkakustannustunteina käytetään $20 \mathrm{~h} / \mathrm{pv}$ ja satotasoksi oletetaan $5000 \mathrm{~kg} / \mathrm{h}$. Mikäli murskauksen palkkakustannustunteina käytetään 2 h/pv, niin saadaan tulokseksi $17 € /$ t. Suuremman sadon huonompi kannattavuus johtuu suhteellisesta EU-tuen pienenemisestä ruokohelpitonnia kohti laskettuna.

Taulukko 1. Yhteenveto ruokohelpibrikettien tuotantokustannuksista kahdella eri satotasolla laskettuna. Vaihtoehdossa 1 (automatisoimaton linja) murskauksessa tarvittavien henkilötyötuntien määränä on käytetty 20 h/vrk ja vaihtoehdossa 2 (automatisoitu linja) murskauksen henkilötyötuntien määränä on käytetty 2 h/vrk.

$\begin{array}{lll}\text { KUSTANNUS } & \text { Sato, 5 t/ha } & \text { Sato, 7 t/ha } \\ \text { Viljely ja korjuu, } € / \mathrm{t} & 93 & 79 \\ \text { Murskaus (vaihtoehto 1), } € / \mathrm{t} & 63 & 63 \\ \text { Murskaus (vaihtoehto 2), } € / \mathrm{t} & 22 & 22 \\ \text { Briketöinti, } € / \mathrm{t} & 15 & 15 \\ \text { Kokonaiskustannukset (vaihtoehto 1), } € / \mathrm{t} & 171 & 157 \\ \text { Kokonaiskustannukset (vaihtoehto 2), } € / \mathrm{t} & 130 & 116 \\ \text { EU-tuet, } € / \mathrm{t} & 113 & 80 \\ \text { Katteeton hinta (vaihtoehto 1), } € / \mathrm{t} & 58 & 77 \\ \text { Katteeton hinta (vaihtoehto 2), } € / \mathrm{t} & 17 & 36\end{array}$




\section{Johtopäätökset}

Ruokohelven kevätkorjuussa peltojen sijainnilla ja kantavuudella on suuri merkitys sadonkorjuun onnistumisen kannalta. Ruokohelpiviljelmät tulisi perustaa ainoastaan kohteisiin, joihin kulkeminen kelirikon aikana raskailla koneilla ja täysperävaunuyhdistelmillä on mahdollista. Perustamisvaiheessa on kiinnitettävä erityistä huomiota pellon tasaisuuteen, sillä epätasainen pelto vaikeuttaa sadonkorjuuta ja aiheuttaa korjuutappioita. Korjuutappioiden määrää ei tässä tutkimuksessa mitattu, mutta silmämääräisesti niitä voitiin kuitenkin selkeästi havaita. Korjuukalustoa tulisi kehittää siten, että korjuutappiot jäisivät mahdollisimman pieneksi ja korjattu sato mahdollisimman suureksi.

Pyöröpaalien alhaisesta tiheydestä ja muodosta johtuen, niiden varastointi ja kuljetus vaativat paljon tilaa. Suuri tilantarve aiheuttaa lisäkustannuksia sekä varastoinnissa että kuljetuksessa. Paalien tiheyttä voitaisiin nostaa käyttämällä korjuussa muuttuvakammioista pyöröpaalainta tai suurkanttipaalainta. Kanttipaalaimella paalattujen paalien muoto on myös edullisempi logistiikan kannalta. Toisaalta kanttipaalain on raskas ja sen hankintahinta on korkea.

Kevätkorjatun ruokohelven briketöinti on mahdollista sekä myös taloudellisesti kannattavaa toimintaa tietyin edellytyksin. Briketit ovat helppoja käsitellä ja niiden kuljetuskustannukset ovat ruokohelpisilppua tai paaleja huomattavasti edullisempia. Brikettien kiintotiheys on yli kuusinkertainen ruokohelpipyöröpaalien kiintotiheyteen verrattuna. Briketöinnistä aiheutuu kuitenkin huomattavia lisäkustannuksia. Pienen ruokohelpipeltopinta-alan sadon briketöintiin ei ole taloudellisesti kannattavaa hankkia kalliita murskaus- ja briketöintilaitteita. Mikäli koneet hankitaan, on niitä käytettävä ympäri vuoden ja vuorokauden ympäri. Tässä tutkimuksessa tarkasteltujen murskaus- ja briketöintikoneiden vuosituotoskapasiteetti oli noin $1500000 \mathrm{~kg}$. Tällaisen ruokohelpimäärän tuotanto vaatii peltopinta-alaa noin 300 ha, mikäli satotasoksi oletetaan 5 t/ha. Pienemmältä ruokohelpipeltopinta-alalta saadun sadon briketöiminen voi myös olla kannattavaa, mikäli briketöintiin voidaan käyttää johonkin muuhun käyttötarkoitukseen hankittua jo olemassa olevaa konekantaa. Esimerkiksi puunjalostustehtaalla voidaan viikolla briketöidä puunjalostusprosessissa syntyvää purua ja viikonloppuna ruokohelpeä, kuten tässä tutkimuksessa tapahtuikin.

Murskauksen kustannukset riippuvat merkittävästi murskauslinjan automatisointiasteesta. Ilman automaattista paalinsyöttökuljetinta murskain sitoo käytännössä yhden työntekijän koko murskauksen ajaksi. Tästä aiheutuu kohtuuttoman suuret kustannukset. Automaattisella paalinsyöttökuljettimella voidaan henkilötyötunteja vähentää huomattavasti ja näin ollen alentaa kustannuksia merkittävästi.

Laboratorioanalyyseissä ruokohelpibriketille saatiin hieman korkeampia lämpöarvoja, kuin mitä kirjallisuudessa esiintyy. Lämpölaitoksen polttokokeessa saatiin lämpöarvoksi myös hyvä tulos, vaikka lämpöenergian kulutus oli kokeen aikana pieni. Laboratoriossa mitatulle kirjallisuutta korkeammalle lämpöarvolle ei löytynyt selitystä. Lämpölaitospolttokokeen aikana vallinneet olosuhteet asettavat tulosten yleistettävyydelle rajoituksia. On todennäköistä, että suuremmalla lämpöenergiankulutuksella lämpölaitoksen hyötysuhde kasvaa ja tuhka käyttäytyy eri tavalla kuin pienellä energian kulutuksella. Ruokohelpibriketin poltosta tarvitaan lisätutkimusta, että voitaisiin arvioida paremmin sen soveltuvuutta lämmöntuotantoon. Selvitettäviä asioita olisivat mm. päästöt ja tuhkan käyttäytyminen.

Ruokohelven viljelyssä EU-tuet kattavat viljelystä ja korjuusta aiheutuvat kustannukset, mikäli sato on enintään noin $7500 \mathrm{~kg} / \mathrm{ha}$. Tutkimuksessa käytetyillä menetelmillä voidaan pienin muutostöin valmistaa brikettiä, joiden tuotantokustannukset ovat $17 € / \mathrm{t}$, kun satotasoksi oletetaan $5000 \mathrm{~kg} / \mathrm{ha}$ ja EU-tuki huomioidaan. Mikäli satotasoksi oletetaan $7000 \mathrm{~kg} / \mathrm{ha}$, niin saadaan tuotantokustannuksiksi $36 € /$ t. Suuremmat tuotantokustannukset suuremmalla hehtaarisadolla ruokohelpitonnia kohti johtuu suhteellisesta EU-tuen pienenemisestä sadon määrän lisääntyessä.

Tämän tutkimuksen tuloksia yleistettäessä on huomioitava mahdolliset alueelliset erot $\mathrm{mm}$. kasvuolosuhteissa, työlajien taksoissa, konekalustossa ja EU-tuissa. Yksittäinen kustannuslaskelma ei ole yleispätevä, vaan todelliset tuotantokustannukset ovat aina tapauskohtaisia ja niiden suuruuteen vaikuttavat monet eri tekijät.

\section{Kirjallisuus}

Burvall, J. \& Örberg, H. 1994. Brikettering av rörflen: teknik och ekonomi. Sveriges lantbruksuniversitet. Institutionen för norrländsk jordbruksvetenskap. Rapport 10:1994. Umeå. 
Flyktman, M. 2000. Ruokohelven seospoltto turpeen ja puun kanssa. Teoksessa Biomassan tuottaminen kuidun ja energian raaka-aineeksi. Tutkimuksen loppuraportti, osa II. Toim. Salo, R. 2000. Maatalouden tutkimuskeskus. Jyväskylän yliopistopaino 2000.

Hemming, M., Maunu, T., Suokannas, A., Järvenpää, M. \& Pehkonen, A. 1996. Agrokuidun tuotanto ja käyttö Suomessa. Tutkimuksen loppuraportti II osa. Ruokohelven korjuu, varastointi ja mekaaninen esikäsittely sekä tuotantokustannukset ja saatavuus. Maatalouden tutkimuskeskus.

Isolahti, M. 2006. Ruokohelpi on satoisa energiakasvi. Teho 2/2006: 8 - 11.

Laurila, J. \& Lauhanen, R. 2006. Ruokohelven (Phalaris arundinacea) korjuun kustannukset ja energiakäytön kannattavuus briketöitynä Kuortaneella. Työtehoseuran maataloustiedote. 7 (592).

Lindh, T., Paappanen, T., Kallio, E., Käyhkö, V., Kaipainen, H., Hokkanen, M. \& Leinonen, A. 2000. Korsibiomassojen irtokorjuumenetelmän kehittäminen seospolttoaineiden tuotantoon. Teoksessa Biomassan tuottaminen kuidun ja energian rakaaineeksi. Tutkimuksen loppuraportti, osa II. Toim. Salo, R. 2000. Maatalouden tutkimuskeskus. Jyväskylän yliopistopaino 2000.

Motiva Oy. 2006. http://www.motiva.fi

Pahkala, K., Isolahti, M., Partala, A., Suokannas, A., Kirkkari, A-M., Peltonen, M., Sahramaa, M., Lindh, T., Paappanen, T., Kallio, E. \& Flyktman, M. 2005. Ruokohelven viljely ja korjuu energian tuotantoa varten. 2. korjattu painos. Maa- ja elintarviketalouden tutkimuskeskus. Jokioinen.

Salo, R. 1998. Ruokohelpiseminaari. Biomassan tuotanto pelloilla ja turvesoilla sekä käyttö energian tuotantoon. Maatalouden tutkimuskeskus. Yliopistopaino.

Slioor, S. 2006. Tilastoja. Teoksessa Energia katsaus 1/2006. Kauppa- ja teollisuusministeriö energiaosasto. Suomen Graafiset Palvelut Oy.

Suokannas, A. \& Serenius, M. 2000. Paalausmenetelmät korsibiomassojen korjuussa. Teoksessa Biomassan tuottaminen kuidun ja energian raaka-aineeksi. Tutkimuksen loppuraportti, osa II. Toim. Salo, R. 2000. Maatalouden tutkimuskeskus. Jyväskylän yliopistopaino 2000.

Tuominen, V. 2006. TE-Keskus Etelä-Pohjanmaa. http://www.isojoki.fi/maatalous/pinta-alatuet_2006.pdf

Tuunanen, L. 1993. Pellolla kasvatetun biomassan polttaminen. Työtehoseuran maataloustiedote. 15 (437). 